\title{
The healing of life within the HIV and AIDS pandemic: Towards a pedagogical reframing of paradigms concerning dysfunctional civil, health and ecclesial systems
}

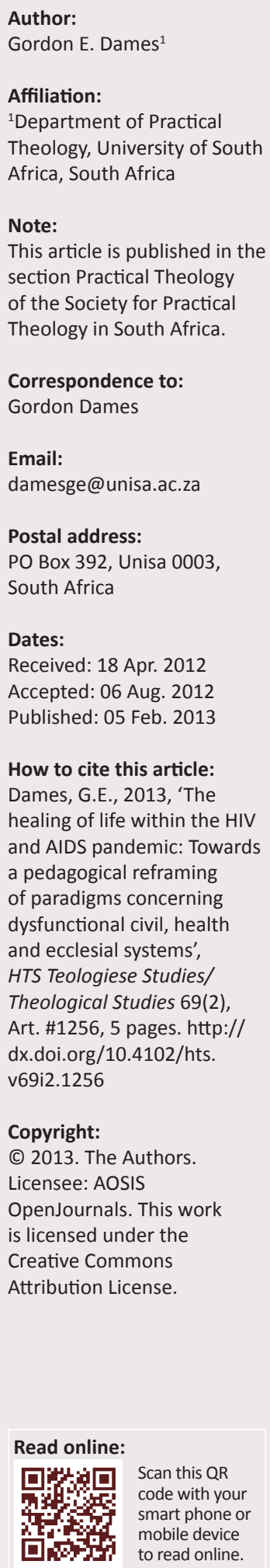

The inability of government, communities and churches to deal with complex HIV and AIDS challenges may foster pathological psychosocial and systemic dysfunctionalities. The reframing of pathological and disempowering pastoral therapeutic and health promotion praxes are sought. The objective was to construct a new pastoral and social therapeutic methodology. It should develop in line with health promotion praxes in strengthening both ecclesial and community health praxes. Reframing agents such as pastoral therapeutic and health praxes, as well as ecclesial and community systems, could ultimately engender a transformative process in transforming pathological HIV and AIDS praxes.

\section{Introduction}

HIV and AIDS is one of many complex pathologies which constitute a challenge to South African society (cf. Shorter \& Onyancha 1998). An inappropriate response could result in a lack of capacity in relating meaningfully to and dealing constructively with this challenge (cf. Naidoo 2008:225). Maluleke (in Bouwer 2006:1) for instance, refers to the 'impotency' of government, community services and the church to address complex existential issues. The lack of capacity by 'impotent' public services may lead to various pathological dysfunctionalities (cf. Dames 2010). 'Pathology' or 'pathological' refers to an intoxicated worldview, or even to ancestral beliefs with a dangerous and destructive uncontrollable power (Manala 2008:93). Pathological dysfunctionalities render communities powerless and cause anxiety, fear, depression, compassion fatigue and hopelessness (Louw 2008:138, 142; cf. Swart, Fourie \& Scheepers 2001; Böhmer \& Spangenberg 2001). These factors lead to disempowerment amongst leaders, society and social systems. It results in exacerbated suffering amongst poor and vulnerable people living with HIV and AIDS. Some exponents have argued that the church in Africa, in the light of the aforementioned challenges, is characterised by alienation, estrangement and prejudice (Brown \& Hendricks 2004). The contextualisation of HIV and AIDS within the African context is critical to address the complexity of the ideal of the healing of life (Louw 2008). The task of the church is to change perceptions of being old, judgemental, uncaring and unloving if it seeks to become a healthy community (Brown \& Hendricks 2004). The church as a healing agent has failed in the past to position itself appropriately to the HIV and AIDS pandemic and concurrent challenges (Buffel 2006:1; Cilliers 2006:13). It should guard against its previous negative perceptions and inappropriate ministry practices, which had a direct disempowering impact on the broader public domain. The contemporary church is called upon to make a renewed public pastoral care contribution to a broken, disempowered and poverty stricken society. Gerkin's $(1997: 25,59)$ plea for 'confrontational care' for social justice, human dignity and moral integrity is crucial in the re-envisioning and creation of a healthy society.

\section{Objective}

This article focuses on the reframing of pathological and dysfunctional paradigms in the HIV and AIDS context. The reframing of both philosophical and systemic pathologies engenders not only new conceptual constructs, but the empowerment of people living with HIV and AIDS. The complexity of the HIV and AIDS pandemic requires a pragmatic and cross-disciplinary approach. Transversal rationality offers an ideal methodology to 'overlap and converge' with different interdisciplinary sciences - pastoral care and counselling, medical science and psychology (Osmer 2008:170ff). Communities of practices were forged during the South African liberation movement's community empowerment programmes. These formational practices demonstrated how poor and suffering communities could simultaneously be empowered on philosophical, socioeconomic and political levels (cf. Institute for Justice and Reconciliation 2004; Wenger 2007). Similar communities of practice for health and wellness empowerment are once again needed. 
This article seeks to address the abovementioned challenge of the HIV and AIDS pandemic. Emphasis will be placed on critical determinants such as disempowering psychosocial, philosophical, socio-economic, political and ecclesial systems. The aforementioned challenges have a direct impact on pastoral and health praxes within the HIV and AIDS pandemic context.

\section{HIV and AIDS in perspective}

The impact of multinational activity on the transference of HIV should be noted, especially in scenarios such as the 2010 FIFA World Cup in South Africa. The South African public - as well as the majority of the world population - should always remain vigilant when diverse world communities congregate. Preventative measures should be developed and implemented to preserve people's health and well-being, the health promotion initiatives already existing within the HIV and AIDS communities notwithstanding. The South African government announced before the 2010 FIFA World Cup that sex work would be legalised and allowed within demarcated public spaces. Such liberties could have caused, and may in future cause, insurmountable harm to the health and wellbeing of local communities and health practices within the HIV and AIDS context.

The multifaceted dynamics of HIV and AIDS are complex and require multidisciplinary health approaches and interventions (Dreyer 2008; MacMaster 2006; Müller 2005).

\section{The socio-economic and political context}

Reflection on health practices within the HIV and AIDS sphere cannot be approached in isolation of the broader socioeconomic and political factors (LenkaBula 2008; Shorter \& Onyancha 1998; Stephens 2008; Van Dyk 2008:133ff.). Health is interwoven with socio-economic and political systems. Poor and vulnerable communities are shaped by these challenges (Shorter \& Onyancha 1998:17). The everyday realities of people living with HIV and AIDS are complex and could potentially disempower health practices and even governmental interventions (Cairncross 2007). The degree to which health practitioners, patients, government and society become unable to 'cope' effectively with health challenges within the HIV and AIDS pandemic, determines ultimately the quality of health and well-being. These challenges are potentially destructive for people's worldviews and human dignity (Coene 1983:950; De Lange 2006; Bouwer 2006). Pastoral care and counselling ought, therefore, to be critical about the socio-economic and political conditions of people living within the HIV and AIDS pandemic. These conditions create and sustain crisis situations for poor and vulnerable people (Moila 1989:208). Poverty in South Africa is predominantly confined to Black people, the poor and vulnerable majority (Cloete 2007:3). Political attempts to redress the realities of the poor remain inadequate (Achmat in Van Dyk 2008:i-ii; cf. Simmons 1989). The fragmented social health projects of the government, non-governmental organisations (NGOs), even of churches, are not enough. These interventions are short-lived and do not succeed in transforming severe socio-economic conditions towards the healing of life in contexts of exacerbated suffering.

Existential as well as psychological challenges for people living with HIV and AIDS in South Africa are characterised by severe poverty and social pathologies such as violence, alcohol and drug abuse, oppression and human rights infringements (Shabodien 2007:1). These challenges pull community health practices $(\mathrm{CHP})$ to the margins of disempowerment and systemic dysfunctionality. Pastoral care and counselling and community health practices are called upon to claim a cross-disciplinary approach in engendering transformation to empower poor and vulnerable people whose lives are affected by the HIV and AIDS pandemic (cf. Gerkin 1997:51, 72ff.). The church needs to redefine and recommit its faith in the light of such human destructiveness (Patton 1988:31). The church should empower communities to reframe strenuous living conditions through life-giving practices (cf. Freire 1978:57). Its cooperation and engagement with public and private health care institutions in a more structured and sustainable manner will help to empower dysfunctional communities and health care institutions (cf. Torfs 1992).

\section{Hermeneutical empowerment and healing of life}

The task of the CHP lies in the reframing of the pathologies in life in terms of a new hermeneutic for the empowerment and healing of life within the HIV and AIDS pandemic. This is not a unique responsibility for the church. However, the need for a renewed hermeneutic is critical to transform pathological conditions and for empowerment practices for the healing of lives. A pedagogic action-hermeneutic of hope for the healing of life through the deconstruction and reconstruction of dysfunctional faith practices is sought (Landman \& Theron 2008:202-203; Patton 1988:31).

Another critical issue for the CHP is the confounding problem of religions that condemn sexual activity and the ramifications this has for the person living with HIV or AIDS' (Jenkins in Aldridge 2000:164). Caring for HIVinfected patients is not only critical, it is extremely complex. The church and CHP should, for instance, also attend to the psychosocial and emotional strain in volunteers and staff caring for HIV-infected persons (Aldridge 2000:164). Pastoral care and counselling, CHP as well as medical practitioners, are being challenged today on another level. Apart from spiritual healing within the context of orthodox medical practices, alternative healing practices such as folk healing practices become crucial in the outcome of well-being and health promotion. This is an emerging glocal ${ }^{1}$ phenomenon that should be critiqued and integrated in healing of life practices:

1.Glocal refers to groups or communities which are willing and able to reflect globally and act locally. Glocalisation serves as a means of combining the idea of globalisation with that of local considerations. The emerging reality of social life globalisation with that of local considerations. The emerging reality of social life
under the conditions of glocalisation provides the preconditions necessary for under the conditions of glocalisation provides the precondition
transnational social spaces global localisation' (Wikipedia n.d.). 
In inner-city New Jersey, HIV-infected Hispanics, aged 23 to 55, receiving care at an HIV/AIDS clinic, and primarily of Puerto Rican origin or descent, believed in good and evil spirits and that such spirits had a causal role in their infection, either alone or in conjunction with ... [HIV]. (Suarez, Raffaelli \& O'Leary 1996:683)

They sought spiritual folk healing for physical relief, spiritual relief and protection from evil. We must be aware of the prevalence of folk beliefs and alternative healing practices and cannot assume when we talk of spiritual healing that it will fit into the sanitised views of a rationalised Western approach. (Aldridge 2000:164)

Traditional healing practices in Africa have, for centuries, demonstrated similar and deep-level prevention and intervention wellness practices (Louw 2008:260ff.; Manala 2008). Any reflection on healing and health practices specifically within the HIV and AIDS pandemic should adopt a cross-disciplinary approach with appropriate traditional healing practices. More people are demanding involvement in health care issues and practices, as well as in wellness projects to promote healthy lifestyles. Contemporary communities require 'symbolic frames and action' for participation in policy development and decision-making. They are refraining 'to abdicate the sole process of decision-making to licensed and expert professionals' (Aldridge 2000:10; Achmat in Van Dyk 2008:i-ii; Simmons 1989:522ff.). Local communities may experience these health workers and professionals as 'outsiders' in terms of their educational background, demography and social class. Health practitioners should also learn from the traditional healers of local communities and become facilitators and advisers within an HIV and AIDS health care system (cf. Zuber-Skerritt 2007). However, within wealthy industrialised nations and societies, health is perceived and treated as an obvious commodity that serves individualistic health care needs. Basic services and issues such as survival needs, nutrition and fresh water are 'taken for granted' and are not being considered as lifethreatening issues. It would seem that the problem in wealthy communities centres about people's existential needs - it is about 'glut rather than poverty' (Aldridge 2000:10).

\section{The role of pastoral care and counselling and health practitioners}

Taylor (1984:228-232) refers to social issues which impact on existing health practices and interventions. Pastoral counsellors and health practitioners will consequently encounter people with existential anxieties which do not stem from their personal lives, but from socio-economic distress factors in the broader community (LenkaBula 2008; Taylor 1984:229).

The reinvention of proactive church (pedagogical) programmes should address the empowerment of local communities towards wellness and health promotion practices. In so doing it should redress pathological socioeconomic and political conditions within poverty stricken communities (Cairncross 2007:1). The impact of socioeconomic challenges on people's living conditions within local communities, as well as on their psychological well- being, cannot be disregarded (MacMaster 2006:1-10; Taylor 1984:228). The potential impact that these conditions may have on the psychosocial health of poor people, as well as people living within the HIV and AIDS pandemic, should be acknowledged and addressed. The church and pastoral counsellors are not responsible for providing comprehensive solutions to these intractable challenges. Instead, pastoral care and counselling should engage in the reframing and transformation of disempowering paradigms and practices. The pastoral care and counselling ministry is an invaluable asset for the church to 'transcend cheap pastoral information and advice' and in concretising and contextualising wellness and healing in HIV and AIDS contexts (Taylor 1984:228).

\section{Contemporary scientific challenges}

Modern science is plagued by the notion of objective knowledge and universal 'truths'. The rationality in modern science presupposes that knowledge and its application applies to all situations, contexts and periods (Keifert 2006:46ff.; Zuber-Skerritt 2007:37ff.). The scientific knowledge and practices of Western and North American societies played a hegemonic role in what problems in other countries with diverse and complex contexts were dealt with and how they were dealt with (Zuber-Skerritt 2007:41). Linear 'universal' answers for multiple challenges, combined with an individual perspective of diverse and complex life issues, determined scientific objectives and outcomes (Keifert 2006:48ff.). Health practices were developed in line with ultra or universal principles. Complexity and divergence in the postmodern era, however, requires a broader 'reflexive equilibrium' approach for psychosocial wellness and healing practices (Osmer 2008:172; Osmer 2010:5-7). Collaborative research partnerships are becoming the norm in scientific communities. The realisation that modern science is incapable of addressing complex global issues necessitates inclusive and integrative scientific approaches (Stephens 2008:6). Signs of integrative scientific work are, for example, evident in pastoral care, the health sciences and psychology (Aldridge 2000; Gerkin, 1997:51, 72; Herholdt 2008; Laverack 2007; Osmer 2006:327ff.; Robertson 2007; Stephens 2008). Cross-disciplinary initiatives between the different scientific disciplines are crucial. The survival of humanity in the 21st century and beyond depends on the extent to which cross-disciplinary approaches are prepared to address global issues such as the HIV and AIDS pandemic and global warming.

\section{Towards an alternative approach}

The aforementioned argument makes it clear that we need an alternative approach which is adaptable and concrete in addressing the complexities of the HIV and AIDS pandemic. The postfoundationalist approach is an example of an alternative approach, discussed in Müller's (2005) article: 'A Postfoundationalist, HIV-positive Practical Theology'. The postfoundationalist approach transcends the limitations and 'insular comfort' of theological foundationalism as well as any form of relativism and the unpredictability of 
anti-foundationalism (Van Huyssteen in Müller 2005:73). Müller (2005:73) holds that practical theology functions timelessly and contextually in and through reflexive Trinitarian praxes. This is a crucial distinction from the traditional practical theology practices which led to institutionalised and maintenance-based ministry activities (Dames 2010). The moment of praxis is 'always local, embodied and situated' - an 'elitist academic affair, with limited contact with the informal forms of practical theological reflection' does not suffice (Müller 2005:73). The scientific quality of practical theology has suffered due to silo and elitist academic practices within local community contexts as well as at informal ministry levels (Dames 2009; Müller 2005:73). However, postfoundationalist practical theology is reinventing the basic practices of practical theology through local and informal formational practices (Müller 2005:74; Landman \& Theron 2008:204-205). Dynamic reflexivity of communal values is critical for health praxes (Stephens 2008:2). The role of prayer or spirituality in relation to medical science could foster a point of convergence for contextual reflexive communal values of health (cf. Naidoo 2008:224-231).

Theology, specifically pastoral care and counselling, needs to adopt a cross-disciplinary or transversal rationality (Dames 2010) or multi-faceted approach with health science, education and social work (Laverack 2007:3). Scientific points of convergence for diverse health contexts are required (cf. Osmer 2008:11-12). The hypothesis is that pathological thoughts, beliefs and practices are, in essence, the primary cause of disempowerment and ultimately disease and illness amongst people living with HIV and AIDS (Louw 2008:138ff.). Dysfunctional socio-economic, political and ecclesial systems exacerbate these conditions. People in general, and people living with HIV and AIDS in particular, are directly and indirectly being disempowered. It is principally and structurally the disablement of hopeful and meaningful living. Meaningful living presupposes the empowerment of persons in living their suffering with hope, courage and resilience (Louw 2004:12).

People living with HIV and AIDS may experience emotional 'inability' or a lack of positive ability to live empowering and affirmative lives (Louw 2008:31). Pathological psychosocial, cultural and religious perceptions, beliefs and practices could further foster a pessimistic view on their health prognosis. Switzer (1986:160) proposes a reflexive population focus as a solution to integrate the church's pastoral care and counselling ministries with multiple community health praxes. Research evidence indicates a growing interest by medical practitioners to adopt a practice of holistic, integrated medicine and prayer (spiritual) healing ministry in their medical praxes (Aldridge 2000; cf. Herholdt 2008; Hestenes 2008; Naidoo 2008).

\section{Methodology for disciplinary impasse}

Pathological paradigms result in varying levels of psychosocial and even systemic dysfunctionalities and require a reframing methodology (Capps 1990). Capps' (1990) reframing methodology is local, embodied, intentional and ideal in addressing the pathological paradigm. Reframing refers to the frame of reference (or perception) which determines the implicit meaning in episodes, events and situations (cf. Osmer 2008). The newly constructed frame, changes meaning - human responses and behaviours become embodied change (Capps 1990:10). Frames are powerful conceptual maps or lenses within relational networks and institutional systems. Conceptual frames or maps change worldviews and decisions about complicated actions and responses (Roxburgh 2005:46). The reframing of meaning seeks a totally different kind of change from the status quo (Capps 1990:11). Deep level change refers to postfoundational (Müller 2005:73) change and a transformed framework.

To reframe, according to Capps (1990) means to:

change the conceptual and/or emotional setting or viewpoint in relation to which a situation is experienced and place it in another frame which fits the 'facts' of the same concrete situation equally well or even better, and thereby changes its entire meaning. (pp. 17-18)

Reframing is thus a powerful conceptual, emotional and psychological map or lens. It replaces pathological philosophies, dysfunctional practices and preconceived solutions to problems. Meaningful and new ways of language, perception and approach are proposed. Reframing empowers persons to transcend limiting preconceptions by embracing broader understandings of human possibilities 'in reconfiguring the past in view of a new future' (Capps 1990:24-25; Cilliers 2006:7).

The reframing of individualistic, fragmented and institutionalised social and ecclesial systems - which impact pathologically and disempower pastoral therapeutic and health praxes - is sought. Reframing would contribute to constructing a new pastoral and social therapeutic methodology. Pastoral care and counselling could strengthen both ecclesial and community systems in realising reflexive equilibrium and communal values in health praxes. The reframing of pathological belief systems, particularly related to HIV and AIDS, could foster new perceptions on wellness and healthy lifestyle praxes. Reframing current methodology could engender effective pastoral therapy and community health praxes, and could help to review ecclesial and community systems and health praxes. This could hold for a transformative reframed hermeneutic and reflexive equilibrium for the healing of life (cf. Fretheim 1984:107ff.). The transformation of pathology towards constructive empowerment and motivation is, therefore, attainable (Louw 2008:31; Strümpfer 2002).

\section{Conclusion}

The HIV and AIDS pandemic signifies a state of disengagement from traditional perceptions of illness and disease. Pastoral theology is called to a new conversion in responding to the HIV and AIDS pandemic. The scope of the HIV and AIDS phenomenon requires a sustainable crossdisciplinary approach. 


\section{Acknowledgements Competing interests}

The author declares that he has no financial or personal relationship(s) which may have inappropriately influenced him in writing this article.

\section{References}

Aldridge, D., 2000, Spirituality, healing and medicine: Return to the silence, Jessica Kingsley, London. PMCid:1118397

Böhmer, A.C. \& Spangenberg, J.J., 2001, 'Depressie en Angs onder Predikante van die Nederduitse Gereformeerde Kerk in die Wes- en Suid-Kaap', Dutch Reformed Theological Journal 42(1/2), 6-14.

Bouwer, J., 2006, 'Human dignity and HIV/AIDS', paper presented at the 2006 Stellenbosch-Kampen Consultation, University of Stellenbosch, Stellenbosch, 14-15 August.

Brown, J. \& Hendricks, H.J., 2004, 'The Aids Fulcrum: The Church in Africa Seesawing Between Alienation, Estrangement, Prejudice and Love', Practical Theology in South Africa 19(2), 19-36.

Buffel, O., 2006, 'Pastoral Care to People Living with HIV/AIDS: A Pastoral Response that is Contextual and Liberating', Practical Theology in South Africa 21(1), 1-18.

Cairncross, L., 2007, 'The challenge of health inequality between the private and public sectors', paper presented at the 2007 Conference of the Ethical Leadership Project, University of the Western Cape, Bellville, 06-07 September.

Capps, D., 1990, Reframing: A new method in pastoral care, Fortress Press, Minneapolis.

Cilliers, J., 2006, 'Preaching as language of hope in a context of HIV and AIDS', paper presented at the 7th International Conference of the Societas Homiletica, Pretoria, South Africa, 05-10 August. PMCid:1676147

Cloete, K., 2007, 'Bridging inequality: Race, class, cultural differences and poverty in the Western Cape: A South African Communist Party perspective', paper presented at the 2007 Conference of the Ethical Leadership Project, University of the Western Cape, Bellville, 06-07 September. PMCid:2598581

Coene, S., 1983, 'Clinical Pastoral Education with the Poor', The Journal of Pastoral Care XXXVII(2), 90-97.

Conyne, R.K., 2004, Preventive counseling: Helping people to become empowered in systems and settings, 2 nd ed, Brunner-Routledge, New York.

Dames, G.E., 2009, 'New Frontiers for Mission in a Post-Modern Era: Creating Missional Communities', Missionalia 35(1), 34-53.

Dames, G.E., 2010, 'The Dilemma of Traditional and 21st-century Pastoral Ministry: Ministering to Families and Communities Faced with Socio-economic Pathologies' HTS Teologiese Studies/Theological Studies 66(2), Art. \#817, 7 pages. http:// dx.doi.org/10.4102/hts.v66i2.817

De Lange, F., 2006, "'Having faith in yourself". Self-respect and human dignity', paper presented at the Stellenbosch-Kampen Consultation, Stellenbosch University, Stellenbosch, 14-15 August.

Dreyer, J.S., 2008, 'Practical Theology and Human Well-Being: An Exploration of a Multidimensional Model of Human Action as Conceptual Framework', Practical Theology in South Africa 23(3), 3-22.

Freire, P., 1978, Pedagogy in process: The letters to Guinea-Bissau, The Seabury Press, New York.

Fretheim, T.E., 1984, The suffering of God, Fortress Press, Philadelphia.

Gerkin, C.V., 1997, An introduction to pastoral care, Abingdon Press, Nashville.

Hestenes, M.E., 2008, 'Religious Medicine: Challenges and Critiques', Practical Theology in South Africa 23(3), 69-86.

Herholdt, M.D., 2008, 'An Integrated Approach to Human Existence with Spirituality as a Facet of Wellness', Practical Theology in South Africa 23(3), 183-200.

Institute for Justice and Reconciliation, 2004, Interfaith solidarity: A guide for religious communities, Amazon Media, Cape Town.

Keifert, P., 2006, A missional journey of spiritual discovery: We are here now: A new missional era, Allelon, Eagle.

Landman, C. \& Theron, J.P.J., 2008, 'The Healing of Intimate Spaces Through the Deconstruction of Religious Discources: Co-constructing Alternative Stories of Faith in the Context of Township Spiritualities', Practical Theology in South Africa 23(3), 201-218.
Laverack, G., 2007, Health promotion practice: Building empowered communities, Open University, Berkshire. PMid:19588613

LenkaBula, P., 2008, 'Poverty, Wealth and Wellbeing and African Feminist Christian Ethics', Practical Theology in South Africa 23(3), 239-260.

Louw, D.J., 2004, A pastoral hermeneutics of care and encounter, 5th edn., Lux Verbi, Wellington. PMCid:1223860

Louw, D.J., 2008, Cura Vitae: Illness and the healing of life, Lux Verbi, Wellington.

MacMaster, L.L.M., 2006, 'Human dignity at the edges of life: Gangsterism on the Cape Flats', paper presented at the Stellenbosch-Kampen Consultation, Stellenbosch University, Stellenbosch, 14-15 August.

Manala, M.J., 2008, 'Pathological and Therapeutic Ambiguity Inherent in African Ancestral Beliefs: Implications for Concerned Ancestors' Christian descendants', Practical Theology in South Africa 23(3), 87-106.

Moila, M.P., 1989, 'The Role and the Function of the Pastoral Counsellor in the Present Crisis in South Africa', Africa Theological Journal 18(3), 196-209.

Müller, J.C., 2005, 'A Postfoundationalist, HIV-positive Practical Theology', Practical Theology in South Africa 20(2), 72-88.

Naidoo, M., 2008, “'Iviyo" as Contextual Spiritual Direction in an African Context', Practical Theology in South Africa 23(3), 219-238.

Osmer, R.R., 2006, 'Toward a transversal model of interdisciplinary thinking in Practical Theology', in F.L. Shults (ed.), The evolution of rationality: Interdisciplinary essays in honor of J. Wentzel van Huyssteen, pp. 327-346, Eerdmans, Grand Rapids.

Osmer, R.R., 2008, Practical Theology: An introduction, Eerdmans, Grand Rapids.

Osmer, R.R., 2010, 'Practical Theology: A current international perspective', paper presented at the Annual conference for the Society for Practical Theology in South Africa, Pretoria, 18 January.

Patton, J., 1988, 'Pastoral Ministry in a Fractured World', The Journal of Pastoral Care XLII(1), 26-36.

Robertson, S., 2007, Understanding men and health: Masculinities, identity and wellbeing, Open University Press, Berkshire.

Roxburgh, A.J., 2005, The sky is falling!?! Leaders lost in transition, ACl Publishing, Eagle.

Shabodien, F., 2007, 'Transformation through land redistribution in the Western Cape', paper presented at the 2007 Conference of the Ethical Leadership Project, University of the Western Cape, Bellville, 06-07 September.

Shorter, A. \& Onyancha, E., 1998, The church and Aids in Africa, Paulines Publications Africa, Nairobi. PMCid:106243

Simmons, P.D., 1989, 'The Pastor as Prophet: How Naked the Public Square?", Review \& Expositor 86(4), 517-532.

Stephens, C., 2008, Health promotion: A psychosocial approach: Health psychology, Open University Press, Berkshire.

Strümpfer, D.J.W., 2002, 'A different way of viewing adult resilience', paper presented at the 34th International Congress on Military Medicine, South Africa, 17 September.

Suarez, M., Raffaelli, M. \& O'Leary, A., 1996, 'Use of Folk Healing Practices by HIVInfected Hispanics Living in the United States, AIDS Care 8(6), 683-690. http:// dx.doi.org/10.1080/09540129650125399, PMid:8993718

Swart, T., Fourie, C.M. \& Scheepers, H.F., 2001, 'Aspekte van Uitbranding by Predikante van die NG Kerk in die Sinode van Suid-Transvaal (1997-1999); Enkele Empiriese Bevindings', Dutch Reformed Theological Journal 42(1/2), 89-100.

Switzer, D.K., 1986, The minister as crisis counselor, 2nd edn., Abingdon Press, Nashville. PMCid:239087

Taylor, R.P., 1984, 'First Aid in Pastoral Care. Pastoral Care and High Unemployment', The Expository Times 95, 228-232. http://dx.doi.org/10.1177/001452468409500802

Torfs, R., 1992, Congregationele gezondheidsinstellingen: Toekomstige structuren naar profaan en kerkelijk recht, Uitgeverij Peeters, Leuven.

Van Dyk, A., 2008, HIV/AIDS care and counselling: A multidisciplinary approach, 4th edn., Maskew Miller Longman, Cape Town.

Wenger, E., 2007, 'Communities of practice', paper presented at the University of the Western Cape Conference, Bellville, 22 June.

Wikipedia, n.d., s.v. 'glocal', viewed 21 June 2011, from (http://en.wikipedia.org/wiki/ Glocalisation

Zuber-Skerritt, O. (ed.), 2007, 'A Brief description of ALAR (Action Learning and Action Research) in leadership development in a range of fields and projects in four African countries through Action Learning and Action Research (ALAR)', workshop materials, AusAID Seminar materials, Griffith University, Queensland in collaboration with the Centre for Higher and Adult Education, University of Stellenbosch. 